\title{
Expansion And International Expansion Of Small-To Medium Sized Firms: The Role Of Finance
}

\author{
Jan Smolarski, (E-mail: jan.smolarski@fek.su.se), University of Stockholm, Sweden \\ Can Kut, University of Stockholm, Sweden \\ Neil Wilner, (E-mail: wilner@unt.edu), University of North Texas
}

\begin{abstract}
Small- to medium-sized firms are expected to show international growth at an early stage. Several factors may affect the outcome of initial efforts to expand and internationalize. Our research examines how equity based venture funding affects SME expansion and internationalization. We divide venture capital financing into two categories: incremental financing where firms receive their venture capital funding in portions and lump-sum venture funding where firms receive their funding in one lump-sum. The results show that type of equity based venture capital financing affect expansion and internationalization. Incremental funding appears more appropriate for firms with high growth rates whereas lump-sum financing appears more appropriate for firms that are internationalizing their operations.
\end{abstract}

\section{INTRODUCTION}

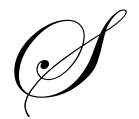

mall- to medium-sized companies (SME's) increasingly compete in the global market place. Understanding variables that affect the success or failure of expansion and internationalization is important. One variable that fundamentally affects how firms expand and internationalize is financing. Financing affects resource acquisition and business operations. This article investigates how method of venture backed equity financing affects firm growth and internationalization. To empirically investigate the affects of method of financing, we divide equity based financing into two groups: lump-sum and incremental. In doing so, we address two important aspects of financing small- to medium-sized firms. First, we go beyond the extant literature, which focuses on debt versus equity financing. Second, we provide descriptive and statistical analyses of how incremental financing and lump-sum financing affect growth and internationalization. The results of the study provide an opportunity for interested parties such as governments, lending institutions and venture capitalists to tailor their financing programs and offerings to firm specific situations.

This paper is organized as follows. The first section combines a literature review with theory development. This is followed, respectively, by a discussion of the research methodology and the main results. The final section provides implications, a summary, conclusions and suggestions for future research.

\section{LITERATURE REVIEW}

In this section we give an overview of relevant research in the internationalization, expansion and financing of small and mid-sized firms. At least three major variables affect firm growth and internationalization: method of expansion, method of financing and principal-agency relationships between the venture capitalist and the firm.

Firm growth and internationalization has been studied extensively with mixed results. Existing literature dealing with internationalization of small and medium-sized firms can be segmented into two main theoretical areas: stage theory (Johanson and Wiedersheim-Paul, 1975) and network theory (Coviello and McAuley, 1999). The stage model used by Gankema, Snuif and Zwart (2000) suggests that internationalization occurs in stages. The network 
model is a view that firms' network relationships are the basis for internationalization (Coviello and McAuley, 1999). Autio, Sapienza and Almeida (2000) suggest that knowledge intensity, age of entry and imitability affect the rate of internationalization. Lee and Tsang (2001) maintain that industrial and managerial experience is one of the dominating factors in venture growth. Orser, Hogarth and Riding (2000) argues that sector, owner gender, size of business, legal structure and firm age affect entrepreneurial performance. Carpenter, Pollock and Leary (2004) found that the presence of venture capital had a negative effect on internationalization but a positive effect when the authors controlled for international experience of the venture capitalists. They also found that US based technology firms are less likely to internationalize.

The financing aspect has been studied in relation to entrepreneurship and small- to medium-sized firms in various respects but it is still a relatively underdeveloped research area. Davila et al (2003) examine firm growth when venture capital financing is present and find a positive relationship between employee growth and the presence of venture capital. Specifically, Davila et al (2003) explore if venture capital leads to growth or whether growth signals the need for a venture capitalist. Davila at al's result suggest that start-ups may delay growth due to lack of financing suggesting that financing plays an important role in promoting growth. Cassar (2004) analyzed financing components and found that debt level is a function of firm size. He also suggests that asset structure plays a role in determining financing options and that a firm intent on growing is more likely to use bank financing. This finding is contrary to Cressy and Olofsson (1997), who found that bank debt has a negative impact on firm growth. Cassar (2004) also found that financing affects growth and export potential. Reid (2001) argues that the choice between debt and equity financing is related to the cost of capital. Fu et al (2002) found a positive relationship between equity financing and profitability. Cowling (2004) argues that profitability affects growth. He suggests that very small firms are ready to forego profits in order to grow but that larger enterprises do not make that trade-off to the same extent. Lu and Beamish (2001) found that international expansion was initially associated with higher costs, low international sales, and initial set-backs in performance. In the initial stages of internationalization performance declined as the firm dealt with its newness in the international market place but performance increased as firms developed new capabilities relating to foreign markets. This suggests a significant time lag between investment in international markets and sales growth. While not conclusive, this supports the proposition that lumpsum financing is better suited for international expansion since firms need to be able to deal with uncertainties surrounding internationalization, as well as the perceived time lag between market entry and international sales growth.

The existing research suggests that equity based financing method has an impact on firm performance in terms of growth and internationalization. The extant research is not always consistent but two trends emerge. First, bank debt appears to have a negative impact on firm growth and internationalization. Second, equity financing appears to increase growth.

Agency-principal problems and costs are caused by two primary reasons: conflict alignment and issues surrounding goal verification. Financial contracts are used to monitor agency costs (e.g., Jensen and Meckling, 1976), which may result from conflicts between venture capitalists and entrepreneurs. In financial and entrepreneurship terms, the principal is primarily concerned with determining the optimal contract structure such as the structure of venture capital equity financing. Principal-agency theory specifically suggests that optimal contracting requires that the principal considers foreseeable future contingencies. In managing the risks resulting from foreseeable and unforeseeable contingencies, complex contracts are formulated to influence the agent's behavior or probability of outcome of a certain event. Behavior-based observation occurs when the principal can observe and verify the agent's behavior. This is typically used in due diligence and other pre-investment stages but also to monitor pre-agreed goals after the venture capitalist has invested. If the agent cannot be observed, the principal will use outcome-based contracting. Examples of outcome based contracts include financial compensation or financing and expenditure control related contracts. Outcome based contracts may also be used during the preinvestment process.

Reid, Terry and Smith (1997) suggest that UK based venture capital firms manage risk within a principalagent framework. Kaplan and Stromberg (2003) also maintain that venture capitalists' primary method of controlling the principal-agent relationship is through financial contracting. Osnabrugge (2000) argue that venture 
capitalists use different financial contracting mechanisms to reduce agency risks. Thus, extant research is broadly supporting the argument that financial contracting is used by the venture capitalists to manage the principal agency relationship.

To summarize, methods of internationalization and growth have been studied extensively. Extant research in this area is primarily concerned with how non-financial factors affect growth and internationalization. The few studies that have been published dealing with financing issues suggest that bank financing and venture financing play an important role in the growth and internationalization for small- to medium-sized firms. Evidence also supports the argument that financing is used to limit agency related risks and that method of financing has an affect on firm performance in terms of growth and internationalization. While existing studies have focused on comparing debt and equity financing, we focus on how the type or method of equity based venture financing affects growth and internationalization. We postulate that firms that are lump-sum financed will exhibit a higher rate of internationalization compared to firms that receive incremental financing. Firms financed incrementally will exhibit a high domestic growth rate compared to firms that are lump-sum financed. We use a variable called Exp.Rat as a measure of internationalization and a variable called S.Growth as a measure of growth rate. We will now discuss the methodology and sample.

\section{METHODOLOGY AND SAMPLE}

\section{Sample}

The relevant population consists of 186 Swedish firms that obtained venture financing and met our size criteria. Only firms with 100 employees or less were included in the sample, avoiding contamination of large firms which are more likely to obtain private equity financing. Data was obtained from the Swedish Private Equity and Venture Capital Association data base of active members. A survey instrument was used to collect the data. The survey included questions about industry classification, revenue, number of external investors, method of financing, sales growth, number of employees, number of customers, and export sales.

Forty-three firms responded in a single mailing representing a 23 percent response rate. In addition to the data obtained from the survey and the annual reports, all responding firms were contacted to verify the method and type of financing. Eighteen firms were classified as having received incremental financing and 25 firms as having received lump-sum financing. Lump-sum financing was defined as receiving financing once in a calendar year period in a single venture financing round. Incremental financing was defined as receiving multiple financing rounds in a calendar year in a single financing round. The single financing round requirement was imposed to avoid contamination of multiple financing rounds within a calendar year.

\section{Methodology}

We use descriptive statistics, in Table 1x, to help to show the breakdown of the data on the variables of interest. In the tables, the data is divided into two subgroups; lump-sum financed companies and incrementally financed companies. First, we employ the Mann-Whitney U to test the similarities of the two populations. We use non-parametric statistics since the data is not normally distributed. We test for differences on three dimensions. The first is sales growth (S.Growth) where our theory suggests that incremental financing will be the predominant form of financing. Second, we examine internationalization (Exp.Rat) where we expect to find a difference in favor of lump sum financing. Finally, we examine for differences in total revenue. We have no theory for this variable and any results are purely explatory.

\section{Hypotheses 1a, b, c:}

$\mathbf{H}_{\mathbf{0}}$ : $\quad$ The distributions of the two populations are identical on a. sales growth, b. internationalization and c. revenues.

$\mathbf{H}_{\mathrm{a}}: \quad$ The two population distributions are not identical. 
We also use multiple regression analysis to investigate relationships between the variables. This is a preliminary analysis that allows us to focus future data collection efforts. Limitations from our sample size and data collection scales prevent us from arriving at strong conclusions. The F-test examines for the existence of linear relationships between the dependent variable and any of the independent variables. Using the t-test, we test the significance of individual regression parameters. The general model is;

$Y=B_{0}+B_{1} X_{1}+B_{2} X_{2}+\varepsilon$

The hypothesis (F-test) for the first regression is as follows:

Hypothesis 2:

$\mathbf{H}_{\mathbf{0}}: \quad \mathrm{B} 1=\mathrm{B} 2=0$

$\mathbf{H}_{\mathbf{a}}$ : $\quad$ Not all the B coefficients are zero ${ }^{1}$

For each independent variable, we apply the t-test as follows:

Hypothesis 3:

$\mathbf{H}_{\mathbf{0}}: \quad \mathrm{B} 1=0$

$\mathbf{H}_{\mathrm{a}}: \quad \mathrm{B} 1 \neq 0$

Hypothesis 4

$\mathrm{H}_{\mathbf{0}}: \quad \mathrm{B} 2=0$

$\mathbf{H}_{\mathrm{a}}: \quad \mathrm{B} 2 \neq 0$

(Where $\mathrm{X} 1$ and $\mathrm{X} 2$ are as defined in note 1.)

The hypothesis (F-test) for the second regression is as follows:

Hypothesis 5

$\mathbf{H}_{\mathbf{0}}: \quad \mathrm{B} 1=\mathrm{B} 2=0$

$\mathbf{H}_{\mathbf{a}}$ : $\quad$ Not all the $\mathrm{B}$ values are zero ${ }^{2}$

For each independent variable, we apply the t-test as follows:

$\underline{\text { Hypothesis } 6}$

$\mathbf{H}_{\mathbf{0}}: \quad \mathrm{B} 1=0$

$\mathbf{H}_{\mathbf{a}}: \quad \mathrm{B} 1 \neq 0$

Hypothesis 7

$\mathbf{H}_{\mathbf{0}}: \quad \mathrm{B} 2=0$

$\mathbf{H}_{\mathrm{a}}: \quad \mathrm{B} 2 \neq 0$

(Where $\mathrm{X} 1$ and $\mathrm{X} 2$ are as defined in note 2.)

${ }^{1} \mathrm{X}_{1}=$ export ratio, $\mathrm{X}_{2}=$ incremental financing, where $\mathrm{X} 2=1$ if method of financing is incremental financing, otherwise 0 .

${ }^{2} \mathrm{X}_{1}=$ export ratio and $\mathrm{X}_{2}=$ lump-sum financing where $\mathrm{X} 2=1$ if method of financing is lump-sum financing, otherwise 0 . 


\section{ANALYSIS AND RESULTS}

In this section, we analyze the impact that method of financing has on growth and internationalization. We first present the analysis for the descriptive statistics, which is followed by the non-parametric tests. Lastly, we show the results from the regression models.

Table 1x shows the descriptive statistical results. $\mathrm{N}$ refers to the number of data for each variable within the subgroups. Max and Min refers to the the maximum and minimum values that exist in the data for that particular variable. "Sum" is the summation of all values for that particular data. Mean refers to the average or expected value of the data and the standard deviation shows how each varible deviates from the expected value or average.

Table 1x

Descriptive Statistics

\begin{tabular}{|l|c|c|c|c|c|c|c|}
\hline & N & Minimum & Maximum & Sum & Mean & $\begin{array}{c}\text { Std. } \\
\text { Deviation }\end{array}$ & Variance \\
\hline REVENUE & 25 & 1 & 199 & 932 & 37.28 & 55.571 & 3088.127 \\
\hline REVENUE2 & 18 & 1 & 299 & 606 & 33.67 & 70.584 & 4982.118 \\
\hline EXP.RAT & 25 & .00 & 1.0 & 13.77 & .5508 & .41877 & .175 \\
\hline EXPRAT2 & 18 & .01 & 1.01 & 9.86 & .5478 & .37982 & .144 \\
\hline S.GROWTH & 25 & .04 & 1.01 & 12.06 & .4824 & .40411 & .163 \\
\hline S.GROW2 & 17 & .04 & 1.01 & 12.03 & .7076 & .39240 & .154 \\
\hline
\end{tabular}

Lump sum financed; Group 1: REVENUE, EXP.RAT and S.GROWTH.

Incrementally financed; Group 2: REVENUE2, S.GROW2 and EXPRAT2.

Group 1 (lump-sum financing) has a higher revenue mean and higher export ratio than Group 2 (incremental financing). Group 2 has a higher sales growth mean with lower than group 1. The descriptive statistics are consistent with our expectations that lump sum (incremental) financing will be used to a larger degree by firms that are interested in internationalization (domestic growth.) The results with respect to revenue are, again, preliminary.

\section{THE MANN-WHITNEY TEST}

The Mann-Whitney test is used to determine if one population mean is greater than the other. Incremental financing is assigned a value of 1 and is the defined group. The value zero is assigned to lump-sum financing. We use the upper limits of the percentages and ratios of each variable

Table 2x

Mean Ranks

\begin{tabular}{|l|c|c|c|c|}
\hline & INC.FIN & $\mathbf{N}$ & Mean Rank & $\begin{array}{c}\text { Sum of } \\
\text { Ranks }\end{array}$ \\
\hline \multirow{3}{*}{ S. GROWTH } & 0 & 25 & 19.02 & 475.50 \\
\cline { 2 - 5 } & 1 & 17 & 25.15 & 427.50 \\
\cline { 2 - 5 } & Total & 42 & & \\
\hline EXP.RAT & 0 & 25 & 21.74 & 543.50 \\
\cline { 2 - 5 } & 1 & 17 & 21.15 & 359.50 \\
\cline { 2 - 5 } & Total & 42 & & \\
\hline REVENUE & 0 & 25 & 22.94 & 573.50 \\
\hline & 1 & 17 & 19.38 & 329.50 \\
\hline & Total & 42 & & \\
\hline
\end{tabular}


In Table 2x, each case is ranked and the mean is calculated. If the groups are randomly selected, the average ranks should be equal. The incrementally financed group has a significantly higher sales growth mean rank, of 25.15. The lump-sum group's export ratio mean (21.74) is slightly higher than the incrementally financed group mean. Revenue appears to have approximately the same mean rank as the export ratio. Table $3 x$ reports p-values.

Table 3x

Test Statistics

\begin{tabular}{|l|c|c|c|}
\hline & S.GROWTH & EXP.RAT & REVENUE \\
\hline Mann-Whitney U & 150.5 & 206.5 & 176.5 \\
\hline Z & -1.662 & -.156 & -.957 \\
\hline Asymp. Sig. (2-tailed) & .097 & .876 & .339 \\
\hline
\end{tabular}

Defined group: INC.FIN (incremental finance group)

The only significant result is on the sales growth variable $(\mathrm{p}=.097)$. As hypothesized, Group 1, incrementally financed firms, exhibit a higher rate of growth. We have the right direction for internationalization where the lump-sum financed group has a higher mean but there is no significance $(\mathrm{p}=.876$. $)$ Results are inclusive on revenue.

\section{REGRESSION 1}

Table 4x shows several measures, which summarizes the model

Table 4x

Model Summary

\begin{tabular}{|c|c|c|c|c|}
\hline Model & R & R Square & $\begin{array}{c}\text { Adjusted R } \\
\text { Square }\end{array}$ & $\begin{array}{c}\text { Std. Error of the } \\
\text { Estimate }\end{array}$ \\
\hline 1 & $.521(\mathrm{a})$ & .271 & .234 & .35895 \\
\hline
\end{tabular}

A Predictors: (Constant), INC.FIN, EXP.RAT

The $\mathrm{R}^{2}$ value is .271 and adjusted $\mathrm{R}^{2}$ of .234 indicates a low fit of the data to the model which may be due to the population size and varying data scales. Never-the-less, the significant linear relationship (F-test in Table 5X) leads us to reject the null hypothesis in $\mathrm{H} 2$ and the significant coefficient values (t-tests in Table 6x) lead us to reject the null hypotheses in $\mathrm{H} 3$ and $\mathrm{H} 4$. These results show that the regression model has explanatory power and indicate that incremental financing has a positive and significant relation with sales growth.

Table 5x

$\operatorname{ANOVA}(\mathbf{b})$

\begin{tabular}{|c|c|c|c|c|c|c|}
\hline Model & & $\begin{array}{c}\text { Sum of } \\
\text { Squares }\end{array}$ & Df & $\begin{array}{c}\text { Mean } \\
\text { Square }\end{array}$ & F & Sig. \\
\hline 1 & Regression & 1.871 & 2 & .936 & 7.262 & $.002(\mathrm{a})$ \\
\hline & Residual & 5.025 & 39 & .129 & & \\
\hline & Total & 6.896 & 41 & & & \\
\hline
\end{tabular}

A Predictors: (Constant), INC.FIN, EXP.RAT

B Dependent Variable: S.GROWTH 
Table 6x

Coefficients

\begin{tabular}{|c|c|c|c|c|c|c|}
\hline \multirow{3}{*}{ Model } & & \multicolumn{2}{|c|}{$\begin{array}{c}\text { Unstandardized } \\
\text { Coefficients }\end{array}$} & $\begin{array}{c}\text { Standardized } \\
\text { Coefficients }\end{array}$ & \multirow{2}{*}{} \\
\cline { 3 - 7 } & & $\mathbf{B}$ & Std. Error & Beta & t & Sig. \\
\hline \multirow{2}{*}{1} & (Constant) & .234 & .105 & & 2.232 & .031 \\
\cline { 2 - 7 } & EXP.RAT & .451 & .139 & .444 & 3.247 & .002 \\
\cline { 2 - 7 } & INC.FIN & .229 & .113 & .278 & 2.032 & .049 \\
\hline
\end{tabular}

A Dependent variable: S.GROWTH

\section{REGRESSION 2}

Using a multiple regression model, we analyze if lump-sum financing and export ratio contain information about the sales growth. As in the previous regression, the $\mathrm{R}^{2}$ and adjusted $\mathrm{R}^{2}$ have low values of .271 and .234, respectively, indicating how well the data fit the model. Never-the-less, the significant linear relationship (F-test in Table 8X) leads us to reject the null hypothesis in H5 and the significant coefficient values (t-tests in Table $9 \mathrm{x}$ ) lead us to reject the null hypotheses in H6 and H7. These results show that the regression model has explanatory power and indicate that lump-sum financing has a negative and significant relation with sales growth.

Table 7x

\begin{tabular}{|c|c|c|c|c|}
\hline Model & R & R Square & $\begin{array}{c}\text { Adjusted R } \\
\text { Square }\end{array}$ & $\begin{array}{c}\text { Std. Error } \\
\text { of the } \\
\text { Estimate }\end{array}$ \\
\hline 1 & $.521(\mathrm{a})$ & .271 & .234 & .35895 \\
\hline
\end{tabular}

A Predictors: (Constant), LUMPSUM, EXP.RAT

Table 8x

$\operatorname{ANOVA}(\mathbf{b})$

\begin{tabular}{|c|c|c|c|c|c|c|}
\hline Model & & $\begin{array}{c}\text { Sum of } \\
\text { Squares }\end{array}$ & Df & $\begin{array}{c}\text { Mean } \\
\text { Square }\end{array}$ & F & Sig. \\
\hline 1 & Regression & 1.871 & 2 & .936 & 7.262 & $.002(\mathrm{a})$ \\
\hline & Residual & 5.025 & 39 & .129 & & \\
\hline & Total & 6.896 & 41 & & & \\
\hline
\end{tabular}

A Predictors: (Constant), LUMPSUM, and EXP.RAT

B Dependent Variable: S.GROWTH

Table 9x

Coefficients (a)

\begin{tabular}{|c|c|c|c|c|c|c|}
\hline \multirow{2}{*}{ Model } & & \multicolumn{2}{|c|}{$\begin{array}{c}\text { Unstandardized } \\
\text { Coefficients }\end{array}$} & $\begin{array}{c}\text { Standardized } \\
\text { Coefficients }\end{array}$ & t & Sig. \\
\hline & & B & Std. Error & Beta & & \\
\hline 1 & (Constant) & .463 & .115 & & 4.028 & .000 \\
\hline & EXP.RAT & .451 & .139 & .444 & 3.247 & .002 \\
\hline & LUMPSUM & -.229 & .113 & -.278 & -2.032 & .049 \\
\hline
\end{tabular}

A Dependent Variable: S.GROWTH 


\section{FURTHER REGRESSION ANALYSES}

We performed multiple regression analysis where we tried to relate method of financing to internationalization (Exp.Rat.). We did not find a significant relationship as our theory suggests. We can provide an informed speculation as to why this happened. Both the incrementally and the lump-sum financed firms have a high amount of international activity. Eighty three percent of the incrementally firms export as do eighty four percent of the lump sum financed firms. Thus, our sales growth variable is not just domestic and is contaminated by the exporting activity. We will attempt to find a sample of incrementally financed firms with little or no international activity in order to remove the contamination. For purposes of brevity we did not include hypotheses or tables in the paper for the insignificant results.

\section{CONCLUSIONS, IMPLICATIONS AND FUTURE RESEARCH}

We applied standard principal-agent theory within an entrepreneurship framework to develop testable hypotheses. We tested the overall hypothesis that method or type of financing affects firm growth and firm internationalization. We did this by using descriptive statistics, non-parametric tests and regression analysis. The results show that on average incrementally financed firms have higher sales growth compared to firms financed through the lump-sum approach. Incremental financing affects sales growth positively while lump-sum financing has a negative affect. This latter result is consistent with $\mathrm{Lu}$ and Beamish (2001). The results also show that firms in the process of internationalizing benefit from lump-sum financing since they have a higher export ratio.

The results suggest that venture capitalists can increase efficiency by selecting the type of financial contract depending on the goal of the principal. We speculate that tight financial monitoring and control is used to align the growth targets of the principal and agent since sales growth is an observable and verifiable goal. Sales growth is controlled by controlling contingent cash flow rights. If sales growth targets are unfulfilled, the venture capitalists may withhold future cash infusion to the firm. Thus, incremental financing has the effect of tightly aligning the goals of the entrepreneur with that of the venture capitalist further suggesting that firms with tight monitoring outperform firms less tightly monitored firms.

The results with respect to the lump-sum financed firms show directionality rather than significance. The following discussion is based on directionality. Lump-sum financed firms outperform incrementally financed firms in internationalizing their operations as measured by the export ratio. We speculate that greater monitoring and other uncertainties surround international expansion. Greater uncertainties surrounding international expansion may require that firms have greater slack to cope with informational and other types of uncertainty. Firms that internationalize face greater informational asymmetries in international markets compared to their domestic markets. In order to cope with additional uncertainties, firms that are in the internationalization phase will benefit from less tightly controlled monitoring.

Policy implications from our results are preliminary and require further study. First, venture capitalists and other financiers may increase the overall efficiencies in their operations by selecting the most appropriate financing options for small- to-medium sized firms. Second, governments, NGOs and other quasi-government institutions will be able to design and implement better policies in the area of entrepreneurship finance, which in turn may result in more efficient outcomes such as increased employment in SMEs.

There are several limitations with our research. We only study a small group of companies within a narrow geographic focus. This affects the generalizability of the study. We did not study other variables that may have an affect on sales growth and internationalization nor did not we take into account interaction effects. International expansion was based solely on geography and ignores culture. Finally, our sample does not include start-up ventures so our results may not apply to persons that are about to enter into entrepreneurship, only to seasoned firms. 
Future research should incorporate culture, interaction effects and other variables, which may help explain firm and entrepreneur behavior. We believe that research dealing with start-up firms and firms financed via microfinancing schemes is important. Finally, a wider geographic focus is a fruitful avenue of future research.

\section{REFERENCES}

1. Autio, E., Sapienza, H., and Almeida, J. 2000. "Effects of Age at Entry, Knowledge Intensity and Imitability on International Growth.” Academy of Management Journal, 43 (5): 909 - 924.

2. Bechetti, L. and Trovato, G. 2002. "The Determinants of Growth for Small and Medium Sized Firms. The Role and Availability of External Finance." Small Business Economics, 19: 291 - 306.

3. Berger, A. and Udell, G. 1998. "The Economics of Small Business Finance: The Role of Private Equity and Debt Markets in the Financial Growth Cycle." Journal of Banking and Finance, 22 (6-8): 613 - 673.

4. Bitler, M, Moskowitz, T. and Vissing-Jørgensen. 2003. "Testing Agency Theory with Entrepreneur Effort and Wealth." Working Paper.

5. Bratton, W. 2002. "Venture Capital on the Downside: Preferred Stock and Corporate Control." Michigan Law Review, 100: 891 - 945.

6. Brophy, D., and Shulman, J. 1992. “A Finance Perspective on Entrepreneurial Research”. Entrepreneurship Theory and Practice, 16 (3), $61-71$.

7. Carpenter, M., Pollock, T. and Leary, M. 2003. "Testing a Model of Reasoned Risk-Taking: Governance, the Experience of Principals and Agents, and Global Strategy in High-Technology IPO Firms." Strategic Management Journal, 24: 803 - 820.

8. Cassar, G. 2004. “The Financing of Business Start-ups.” Journal of Business Venturing, 19: 261 - 283.

9. Chaganti, R, DeCorolis, D., and Deeds, D. 1995. "Predictors of Capital Structure in Small Ventures." Entrepreneurship Theory and Development, 20 (2): 7 - 18.

10. Chittenden, F., Hall, H., and Hutchinson, P. 1996. "Small Firm Growth, Access to Capital and Financial Structure: Review of Issues and Empirical Investigation.” Small Business Economics, 8 (1): 59 - 67.

11. Coviello, N., and McAuley, A. 1999. "Internationalization and the Small Firm: A Review of Contemporary Empirical Research.” Management International Review, 39 (3): 223 - 256.

12. Coviello, N., and Martin, K. 1999. "Internationalization of Service SMEs: An Integrated Perspective From the Engineering Consulting Sector." Journal of International Marketing, 7 (4): $42-66$.

13. Cowling, M. 2004. "The Growth - Profit Nexus." Small Business Economics, 22: 1-9.

14. Cressy, R. and Olofsson, C. 1997. European SME Financing: An Overview. Small Business Economics, 9: $87-96$.

15. Davina, A., Foster, G. and Gupta, M. 2003. "Venture Capital Financing and the Growth of Start-up Firms." Journal of Business Venturing, 18: $689-708$.

16. Fu, T., Ke, W., and Huang, Y. 2002. "Capital Growth, Financing Source and Profitability of Small Business: Evidence from Taiwan Small Enterprises.” Small Business Economics, 18: 257 - 267.

17. Gankema, H., Snuif, H., and Zwart, P. 2000. "The Internationalization Process of Small and Medium-sized Enterprises: An Evaluation of Stage Theory.” Journal of Small Business Management, 38 (4): 15 - 27.

18. Gompers, P and Lerner, J. 1998. "Venture Capital Distributions: Short-Run and Long-Run Reactions." The Journal of Finance, 53 (6): $2161-2183$.

19. Huyghebaert, N. 2001. The Capital Structure of Business Start-ups: Determinants of Initial Capital Structure. Review of Bank Finance, 2: 84 - 88.

20. Jensen, M. and Meckling, W. 1976. "Theory of the Firm: Managerial Behavior, Agency Costs and Ownership Structure.” Journal of Financial Economics, 3: 305 - 360.

21. Johanson, J., and Wiedersheim-Paul, F. 1975. "The Internationalization of the Firm: Four Swedish Case Studies." Journal of Management Studies, 12: 305 - 322.

22. Jones, M. 1999. "The Internationalization of Small High-Technology Firms." Journal of International Marketing, 7 (4): 15 - 41.

23. Kaplan, S. and Stromberg, P. 2003. "Venture Capitalists as Economic Principals." NBER Reporter, X: 22 -25 . 
24. Kaplan, S. and Stromberg, P. 2001. "Venture Capitalists as Principals: Contracting, Screening and Monitoring." American Economic Review, 91 (2): 426 - 430.

25. Lee, D., and Tsang, E. 2001. "The Effects of Entrepreneurship Personality, Background and Network Activity on Venture Growth." Journal of Management Studies, 38 (4): 583 - 602.

26. Lu, J., and Beamish, P. 2001. "The Internationalization and Performance of SMEs." Strategic Management Journal, 22 (6/7): $565-586$.

27. Manigart, S. and Struyf, C. 1997. "Financing High-Technology Start-ups in Belgium: An Explorative Study." Small Business Economics, 9 (2): 125 - 135.

28. Michaelas, S., Chittenden, F. and Poutziouris, P. 1999. "Financial Policy and Capital Structure Choice in UK SMEs: Empirical Evidence from Company Panel Data." Small Business Economics, 12 (2): 113 - 130.

29. Orser, B., Hogarth-Scott, S., and Riding, A. 2000. "Performance, Firm Size and Management Problem Solving." Journal of Small Business Management, 38 (4): 42 - 58.

30. Osnabrugge, M. 2000. "A Comparison of Business Angel and Venture Capitalists Investment Procedures: An Agency Theory-based Analysis." Venture Capital, 2 (2): 91 - 109.

31. O'Gorman, C. 2001. "The Sustainability of Growth in Small- and Medium-Sized Enterprises." International Journal of Entrepreneurial Behavior and Research, 7 (2): 60 - 75.

32. Reid, G. 1999. "The Application of Principal-Agent Methods to Investor-Investee Relations in the UK Venture Capital Industry." Venture Capital, 1 (4): 285 - 302.

33. Reid, G. 2003. "Trajectories of Financial Business Structure." Small Business Economics, 20: 273 - 285.

34. Reid, G., Terry, N. and Smith, J. 1997. "Risk Management in Venture Capital Investor-Investee Relations." The European Journal of Finance, 3: 27 - 47.

35. Westhead, P., Wright, M., and Ucbasaran, D. 2001. "The Internationalization of New and Small Firms: A Resource Based View.” Journal of Business Venturing, 16 (4): 333-358.

36. Zahra, S., Ireland, R., and Hitt, M. 2000. "International Expansion by New Venture Firms: International Diversity, Mode of Market Entry Technological Learning and Performance." Academy of Management Journal, 43 (5): 925-950. 